\title{
The Whole Campus Is the Library: A Four-Entrance Management Strategy of a Library
}

\author{
Hsinshi Chang \\ Director of the Library \\ The Affiliated High School of \\ National ChengChi University \\ Taiwan \\ Chenfu Lee \\ English Teacher \\ The Affiliated High School of \\ National ChengChi University \\ Taiwan
}

\begin{abstract}
Discarding the traditional one-entrance design, the AHS library provides four entrances for readers. This multi-entry design brings challenges to the library management. However, with the school rationale and vision, freedom, autonomy, creativity, and energy, this new design tries to promote the use rate, to meet the demand of multi-learning, and to prepare all the students for further study. With the promotion of character education and with the trust on the students' self-discipline, the AHS library insists no detection system be set by the entrance; thus the library becomes the field of learning how to behave themselves. To promote the use rate, the AHS library adopts digital and non-digital devices to extend its territory. The establishment of wireless network and the MOD system enable the teachers and students to access the needed information at every corner, the classroom shelves and reading groups erect a library branch in each space. Therefore, the conflicts of hybrid environments are reduced and the four entrances stand for not only the concrete entry but the multiple accesses to the library.
\end{abstract}

\section{The Establishment of the AHS Library}

The Affiliated High School of National ChengChi University (AHS hereafter) began its planning in 1998 and was founded in 2005. Cooperating with the Education Department in National ChengChi University (NCCU hereafter), the AHS aims to fulfil the educational ideals and to become "a high school in the new era."

The first principle, Prof. Chih-Min Tang, is an expert of school building. He was designated to build an affiliated high school at a gentle slope. He insisted that the AHS should take the advantages of the east and west. To meet the school's demands, Prof. Tang invited specialists in education, architecture, curriculum and the community to join the design of the campus. Those planners expected themselves to build a good quality school building and a unique school library, a library that could provides students with comforts in study and learning. 


\section{A Library of Students and Teachers}

The AHS devotes itself to establishing a library of students and teachers and uses school rational and visions as bases to run the library. To obtain a rough sketch of the AHS library, this section will provide a brief introduction of physical environment in section 2.1, school rationale and vision in section 2.2, and response from the users in section 2.3.

\subsection{Physical Environment}

Located on the fifth and sixth floor, the library has two entrances on the fifth floor and two entrances on the sixth. It has an area of $1148 \mathrm{~m}^{2}$, including the periodicals area, webPAC area, new books display area, reading area, comic corner, open stacks area, newspaper reading area, circulation desk, and office on the fifth floor, and reference area, multimedia area, group study room, reading room, and photocopier room on the sixth floor. The library is the most spacious room in the AHS. It is equipped with 234 shelves and provides 256 seats and 60 desks for students, teachers, and the staffs. So far the library contains 4,442 books, 69 kinds of magazines, 15 sets of audio-video hardware, and 66 kinds of software. Besides, the library also provides digital services, with which users can link to 315 on-line database or access the video information through MOD system. Due to the budget control for the firstyear school, the library has only one librarian but 38 volunteers.

\subsection{School Rationale and Vision}

As mentioned in section 2.1, the library has only one librarian to maintain its function. Thus volunteers become a very important resource to run the library. With four entrances, most people will consider how to keep the books from being stolen away. The AHS, however, tries to think about this question from another viewpoint. Since the book thefts cannot be avoided, the library can be viewed as a field of character education. To achieve this goal, the AHS adopts the UNESCO's "Four Pillars" as school rationale and freedom, autonomy, creativity, and energy as its vision.

2.2.1 School Rationale The AHS rationale includes four elements: (1) learning to know, (2) learning to do, (3) learning to live together, and (4) learning to be. Learning to know aims to help students' discovering their learning processes by developing their concentration, memory skills, and the ability to think. Learning to do transfers students' knowledge into practice and therefore every one becomes a student with personal competence. Learning to live together implies the discovering other people and the respect of human diversity. At last, learning to be encourages self-fulfilment. Each one plays his own role---as an individual, a member of the family, a citizen, or any role he or she wants to play.

2.2.2 School Vision Freedom, autonomy, creativity, and energy are the school vision of the AHS. The school believes that freedom is the expression of autonomy, autonomy is the core of freedom, creativity is the source of energy, and energy is the gallop of creativity. When students graduate from schools, they are estimated to become the new citizens of the 21st century and to develop a love for both their hometown and the whole world.

2.2.3. A Library of School Rationale and Vision With the school rationale and vision, the AHS library regards itself as a field of character education. In the library, the students out of their own free will acquire the knowledge on their own. They learn how to 
behave themselves in the library. Without detection systems, everyone in the library is considered to be a human being but not a thief. As a result, the library is not only a place for books but a field of knowledge and character education.

\subsection{Responses}

To examine whether the students understand the school rationale and visions, and management strategy, a survey is held. Among 466 students and the staffs, 257 valid questionnaires are collected and analyzed. Each question asks the informant to degree his or her own agreement or satisfaction of the statement. A maximum of 5 points is given to show the most agreement or satisfaction, while the extreme disagreement or dissatisfaction will be graded 1 point.

When asked about the school vision, 73.16 percents of the informants think they well understand or understand the school vision, 24.51 percents shows no comment, and 2.33 percents say they do not or have the least understanding of the school vision. The average score of this question is 4.0 .

When asked whether they can comprehend the meaning of the school rationale, 74.68 percents of informants state they well understand or understand the school rationale, in contrast with 1.42 percents say they do not or have the least understanding of the school vision. This question has an average of 3.9 points.

As many as 74.68 percents of the informants show their willingness to fulfil school rationale and vision, in contrast with 0.65 percents of informants, who do not want to carry out the school rationale and vision.

Most informants (80.16 percents) claim that they are reliable and honest readers, but only 41.25 percents of the informants agree that the library need no detection systems; 23.35 percents of the informants even think that a library without detection systems is worrying.

Whereas almost three-fourths of the students view themselves as students of the AHS rationale and vision, only two-fifths of the students have confidence on themselves or their schoolmates in that they can be trusted to be a good reader. Such results shows that the connection between the school rational, vision, and the users' expected behaviour in the library is still waiting to be established. This will also be the library's future goal.

\section{The Campus Is the Library}

Considering the digital impact faced by ordinary libraries, the AHS library tries another way to attract its users. First of all, the library is designed more easily accessible. Considering creating more convenience, the library has two entrances on the fifth and sixth floor respectively. According to the survey, 66.54 percents of informants agree that the fourentrance design promotes the service efficiency. Then, the library sets in each classroom a bookcase. The teachers and students can provide and share their books with others. Besides, each class has its reading clubs guided by teachers or community parents. The library hopes to form an atmosphere that reading is fun and joyous. This goal can be achieved not only by the school itself but by the participation of the community. 
The AHS library never ignores the influence of digitalization. The whole campus provides wireless service so that any one can link to the library any time as he or she wants. The MOD system enables students and teachers to access the audio and video information at very corner. With internet, the whole campus is the library.

\section{Conclusion}

The AHS library tries its best to create a user-friendly environment. It has four entrances to draw more users come into the library. Coming with these entrances, book theft becomes a worrying problem. Instead of applying detection systems, the AHS uses a more educational way. Through the school visions and rationale, the AHS expects itself to become the field of character education. Those who come to the library not only acquire knowledge but also learn to appreciate others and respect others. To bring the most benefits to the users, the AHS library extends its territory to the whole campus by setting bookcases in the classroom, holding reading clubs, and providing the wireless service to surf the internet. Even the information center of the library was set down the floor but not in the library. The four entrances serves not only as doorways for users to come and leave the library, they also symbolize that in AHS, everyone can have multiple ways to access the library.

\section{References}

Brophy, Peter, Shelagh F., and Zoe C. (2002) Libraries Without Walls: The Delivery of Library Services to Distant Users. Proceedings of an International Conference Organized by the Centre for Research in Library and Information Management. .

Duer, Marg, Adam P., and Mark V. (2002) Character Education Effectiveness. MA. Thesis: Saint Xavier University.

Finck, Chip, Cynthia H., and Jane J. (2003). Improving Student Achievement Through Character Education. MA. Thesis: Saint Xavier University.

Moore, D. P. (2002). School Building Day. School Planning \& Management, 41:5, 12-13.

Noddings, Nel. (2002). Educating Moral People: A Caring Alternative to Character Education. NY: Teachers College Press.

Purpel, David E. (1999). Moral Outrage Education. NY: Peter Lange Publishing.

UNESCO. (1998). Education for the Twenty-First Century: Issues and Prospects. Paris: UNESCO Publishing. . (2005). 139, 12-19. 
Reproduced with permission of the copyright owner. Further reproduction prohibited without permission. 